\title{
Dioscorea compacta (Dioscoreaceae), a new endangered dwarf species from the Jalapão region, Tocantins, Brazil
}

\author{
Diogo Araújo ${ }^{1}$, Guilherme Medeiros Antar $^{2}$ \& Julio A. Lombardi ${ }^{1}$
}

Summary. The Jalapão region located in the east of the state of Tocantins, central Brazil is the largest continuous area of protected cerrado, a hotspot of biodiversity. Here we present a new species of Dioscorea, found in dry soils in sandy open cerrado vegetation within the limits of two protected areas. This species differs from other similar species by its combination of dwarf habit, staminate flowers with three stamens plus three staminodes, compact pistillate inflorescences and spheroid unwinged seeds.

Key Words. cerrado, endemic species, grasslands, taxonomy.

\section{Introduction}

Dioscoreaceae comprises four genera and c. 650 species distributed mainly in tropical and subtropical regions (E-monocot 2015). Among the genera, Dioscorea L. (including Rajania L.) has the largest number of species and widest distribution. Most of the genus is Neotropical, with Brazil having the greatest number of species of any country in the world, at 139 (Kirizawa et al. 2015). These are distributed throughout the country, especially in seasonally dry environments, e.g. in the cerrado and semideciduous forests, and c. $75 \%$ of the species are endemic.

Dioscorea species are mostly dioecious, stemclimbing plants, with an underground system that is perennial at least in part. Their leaves are mostly alternate; petiole with a pulvinus at each end; inflorescences axillary racemes, panicles, spikes or combinations of these, flowers unisexual, with 6 sepaloid tepals, pistillodium or staminodium sometimes present, 3 - 6 stamens, free, connate to tepals or into a staminal column; style 3-fid, 3-lobed, sometimes with bifid ends, ovary 3-locular. Fruit a 3-winged capsule or rarely a berry, usually with two winged seeds per loculus (Caddick et al. 2002).

Knuth (1924) divided the genus based mainly on the characters of the fruit and seed wing. Thus, subgenus Dioscorea (Eudioscorea) was comprised of species with a circular wing around the seed, and species of the subgenus Helmia (Kunth) R. Knuth characterised by an oblong wing directed towards the base of the seed. The subgenera were subdivided into sections, 17 for Helmia and 39 for Dioscorea, based mainly on inflorescence and staminate flower morphology, but with unclear and arbitrary definitions, in contrast to the monophyly of the genus, as stated by Wilkin et al. (2005) based on molecular phylogenetic studies.

As the majority of Dioscorea species have winged seeds for wind dispersal (Burkill 1960), taxonomists have used the absence of this trait to justify different genera: Epipetrum Phil., Tamus L., Borderea Miégev., Nanarepenta Matuda and Rajania L. (Viruel et al. 2010). Although these taxa are now considered among Dioscorea, there is morphological and biogeographical evidence that wingless seeds have arisen more than once within the genus: the MediterraneanMacaronesian D. communis (L.) Caddick \& Wilkin with its berry fruit, instead of capsule; the Caribbean species of Rajania with samaroid fruits; the dwarfs, D. gillettii Milne-Redh. and D. kituensis Wilkin \& Muasya from east Africa; D. pyrenaica Bubani \& Bordère ex Gren. and D. chouardii Gaussen from the French and Spanish Pyrenees; and Epipetrum species from the Chilean Andes (Wilkin et al. 2009).

Dwarf species are short, usually less than $50 \mathrm{~cm}$, entirely or occasionally missing a climbing stem, appearing as self-supported or prostate herbs. This habit has developed in a great number of species in African savannah, with no parallel evolution in Asia, but some in the New World (Burkill 1960). Besides Epipetrum, the Mexican Dioscorea minima B. L. Rob. \& Seaton and D. multinervis Benth. (Sosa \& Valdivieso 2013), once treated as genus Nanarepenta. In Brazil, most of them occur in high altitude open vegetation

\footnotetext{
Accepted for publication 6 April 2016. Published online 27 April 2016

1 Instituto de Biociências de Rio Claro, Departamento de Botânica, Universidade Estadual Paulista - UNESP, Av. 24 A 1515, Bela Vista, 13506-900, Caixa Postal 199, Rio Claro, São Paulo, Brazil. e-mail: diogoambientais@gmail.com

2 Departamento de Botânica, Instituto de Biociências, Universidade de São Paulo, Herbário SPF, Rua do Matão 277, 05508-090, São Paulo, SP, Brazil.
} 
(Couto et al. 2014) from central-northern to southeastern cerrado (Kirizawa et al. 2015). D. anomala Griseb., D. maianthemoides Uline ex. R. Knuth and D. stenophylla Uline, in the Espinhaço Mountains of Goiás and Minas Gerais; D. perdicum Taub. in the Serra do Mar highlands of Minas Gerais and Rio de Janeiro (Pedralli 2002); and D. sphaeroidea R. Couto \& J. M. A. Braga, from high altitude grasslands in Rio de Janeiro.

The Jalapão region, located in the far east of the state of Tocantins, is the largest continuous area of protected Cerrado in Brazil (Silva \& Bates 2002), a domain with high endemism (Forzza et al. 2012) and threats from human activities (Klink \& Machado 2005). The principal conservation units in this area are Parque Estadual do Jalapão, Estação Ecológica Serra Geral do Tocantins, Parque Nacional das Nascentes do Parnaíba and Área de Proteção Ambiental do Jalapão (Schimidt et al. 2007), all these herein called Jalapão Protected Areas (JPA), where vegetation is well conserved and mostly composed of swamp forests, (locally called "veredas"), and open cerrado vegetation on nutrient-poor sandy soils (Sampaio et al. 2008). The weather is distinctly seasonal, a characteristic of the Cerrado domain (Ratter et al. 1997), the mean precipitation is approximately $1500 \mathrm{~mm} /$ year, and mean temperature is around $26^{\circ} \mathrm{C}$, with a rainy season from October to March and a dry season from April to September (Seplan 2012), when human-induced burns usually happen in the area (Schimidt et al. 2007). Despite this level of protection and its recognised importance for conservation, few botanical expeditions have taken place there, and so the flora is poorly known (Proença et al. 2007).

\section{Material and Methods}

During examination of Dioscorea collections currently deposited in the SPF herbarium (for the masters thesis of the second author), we found two samples of a new species. This was confirmed by bibliographic survey and comparison with specimens from ASE, B, BHCB, CEPEC, CESJ, CGMS, CEN, CONC, EAC, HPL, HRCB, HST, HUESB, HVASF, HXBH, IAC, IEF, INPA, IPA, JPB, K, LP, LPB, M, MAC, MBML, MG, MVA, MVFA, NY, OUPR, PAMG, PEUFR, RB, SGO, SI, SP, SPF, TANG, UB, UEC, UFMT, UFP, UFPI, UFRN, VIC and VIES. Duplicates were sent to $\mathrm{K}$ and HRCB (herbaria acronyms follow Thiers, continuously updated). Accepted plant names follow Kirizawa et al. (2015).

The new species was described and drawn from herbarium specimens. Morphological analysis, photographs and measurements of the rehydrated reproductive structures were undertaken using Leica IC80 camera coupled to a Leica M60 stereomicroscope. For Conservation Status, Extant of Occurrence (EOO) and Area of Occupancy (AOO), the Land-cover change map layer between January 2004 to December 2014 was assessed using the GeoCat tool (Bachman et al. 2011), and standard cell size as proposed by IUCN (2012). The distribution map was produced with QGIS version 2.8.1 (Quantum GIS Development Team 2015).

\section{Taxonomic Treatment}

Dioscorea compacta D. Araújo sp. nov. Type: Brazil, Tocantins: Mateiros: Estação Ecológica Serra Geral do Tocantins, caminho para o rio Verdinho, G. Antar, $H$. Antar $\mathcal{E}^{\circ}$ Nascimento 731 (holotype SPF; isotype K).

http:/ /www.ipni.org/urn:lsid:ipni.org:names:60471722-2

Underground system an ovoid-conical tuber $1.5 \times 1.0$ $\mathrm{cm}$, with a single aerial stem, light brownish periderm and white inside. Stems, to $40 \mathrm{~cm}$ long, slender, initially erect, then prostrate, sometimes climbing, dextrorse. Leaves alternate, entire; petiole to $0.5 \mathrm{~cm}$ long; blade $3-4.5 \times 0.8-2.5 \mathrm{~cm}$, bright green above, pale green below, membranaceous, ovate to lanceolate, base cordate, apex acute, veins $3-7$, prominent on abaxial suface. Staminate inflorescences to $6.5 \mathrm{~cm}$ long, branched main axis bearing cymes with highly reduced internodes, $1-7$ flowers per node, bracts 2.5 - $3 \mathrm{~mm}$ long, lanceolate, right curved, mucronulate; flowers sessile, bracteoles $1.5-2.5 \times 0.5-0.8 \mathrm{~mm}$, ovate, apex rounded, mucronulate, perianth tubular, $3 \mathrm{~mm}$ long, green, white at apex, tepals free at the middle, $1.3-1.5 \times 0.5-0.8 \mathrm{~mm}$, oblong; stamens 3 , base connate, inserted at the base of the perianth, filaments c. $1 \mathrm{~mm}$ long, anthers basifixed, extrorse, staminodes 3, alternate with stamens; pistillode $0.2-$ $0.3 \mathrm{~mm}$, terete, columnar, apically 3-lobed. Pistillate inflorescence to $0.5 \mathrm{~cm}$ long, simple, compact, one per node; bearing up to 7 sessile flowers, $4 \mathrm{~mm}$ long, one per node of the rachis, bracts two, $2-3 \times 0.5-0.7$ $\mathrm{mm}$, narrowly ovate; perianth campanulate, tepals free, $1 \times 0.5 \mathrm{~mm}$, mostly whitish, ovate, acute, ovary 3-carpellate, style c. $1 \mathrm{~mm}$ long, columnar, trifid at the apex, each branch 2-lobed; staminodes 3, c. $0.1 \mathrm{~mm}$ long, antheriform; ovary 3-angled, carpels fusion conspicuous. Capsules $8-9 \times 6.8-7 \mathrm{~mm}$, light green when immature, brownish when mature, roundedobovate in outline, 3-winged, two seeds per locule; seeds spheroidal, wings absent, testa dark brown, colliculate. Figs 1, 2.

RECOGNITION. A dwarf species, similar to D. sphaeroidea R. Couto \& J. M. A. Braga based on dimensions and fruit/seed morphology, but differing on filament length, $0.5 \mathrm{~mm}$ in D. sphaeroidea and $1 \mathrm{~mm}$ in D. compacta; pistillode shape, flattened and columnar; style length, $0.5 \mathrm{~mm}$ and $1 \mathrm{~mm}$, respectively.

DISTRIBUTION. Only known from Jalapão region, central Brazil. (Map 1). 


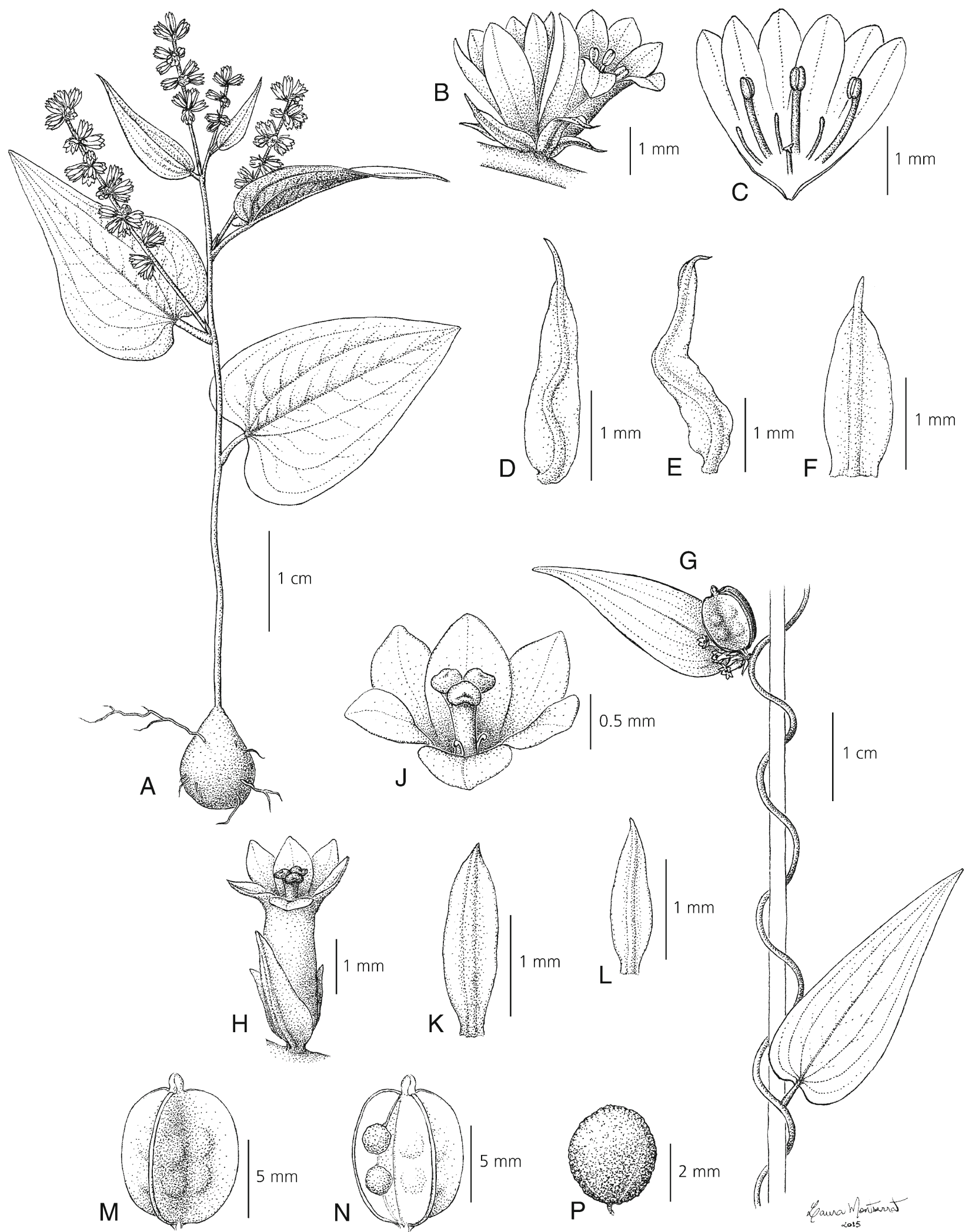

Fig. 1. Dioscorea compacta. A habit, staminate plant; B secondary axis of staminate flower; C dissected staminate flower; D - E bracts of staminate inflorescence; $\mathrm{F}$ bracteole of staminate flower; $\mathrm{G}$ right-twining stem, pistillate plant; $\mathrm{H}$ pistillate flower, frontal view; J pistillate flower, apical view; $\mathrm{K}$ bract of pistillate inflorescence; $\mathrm{L}$ bracteole of pistillate flower; $\mathrm{M}-\mathbf{N}$ fruit; $\mathrm{P}$ seed. DRAWN BY LAURA MONTSERRAT. 


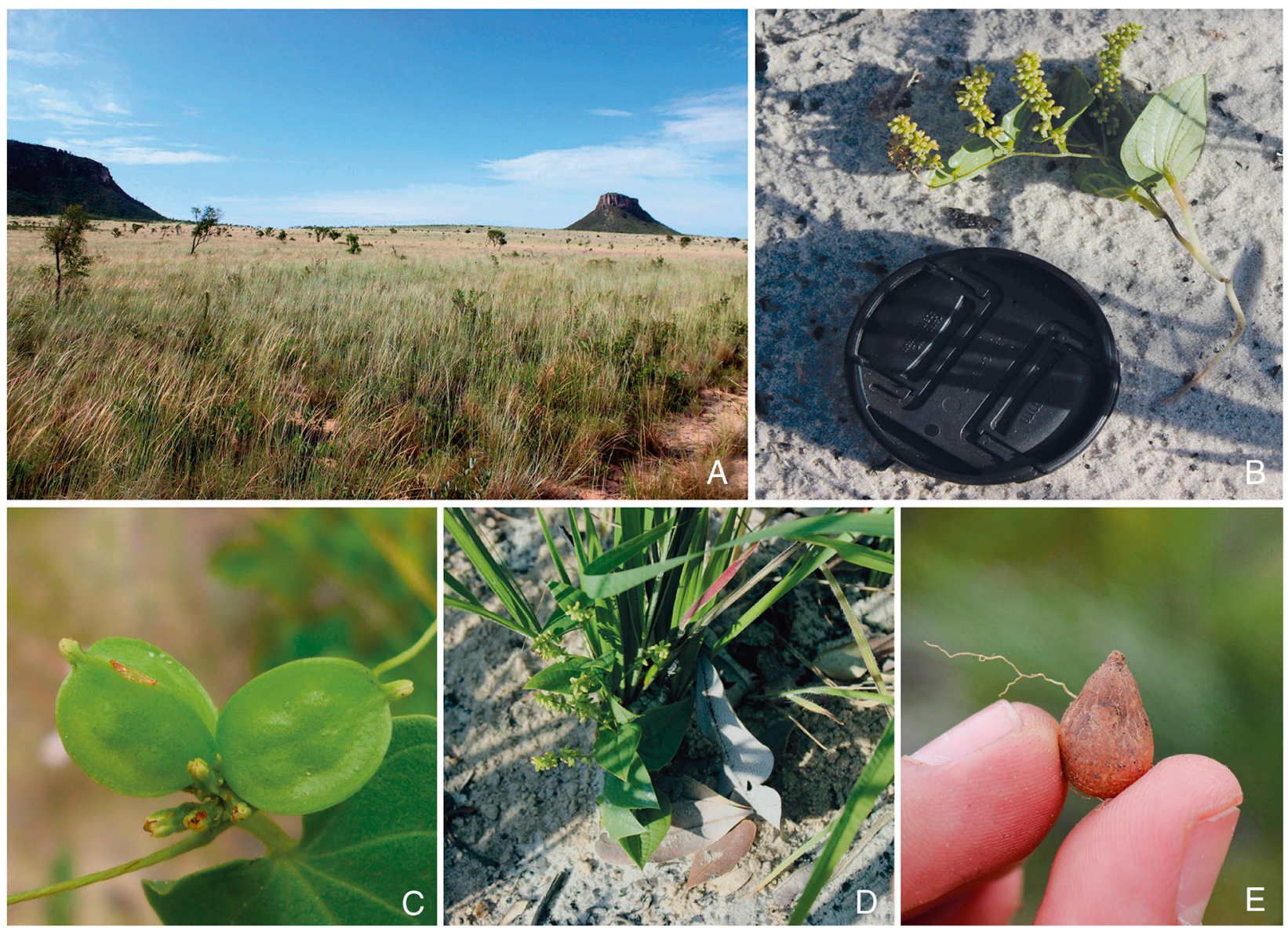

Fig. 2. Dioscorea compacta. A habitat; B habit; C fruits; D twining up sedges; E tuber. PHOTOS BY: GUILHERME MEDEIROS ANTAR

SPECIMENS EXAMINED. BRAZIL. Tocantins: Mateiros: Estação Ecológica Serra Geral do Tocantins, caminho para o rio Verdinho, G. Antar, H. Antar E Nascimento 731 (holotype SPF; isotype K); Estrada entre Mateiros e Coaceral, 13 Nov. 2011, J. B. Bringel et al. 883 (UB); Área de Proteção Ambiental do Jalapão, campo próximo a Fazenda Lua Cheia, acessado pela antiga estrada São Felix-Mateiros, 23 Jan. 2014, G. Antar Eु L. F. Nascimento 374 (SPF); Parque Estadual do Jalapão, próximo à sede do Parque Estadual do Jalapão, 3 Feb. 2015, G. Antar E H. P. Antar 801 (HRCB, SPF).

HABITAT. Between 500 and $600 \mathrm{~m}$ a.s.l. in dry soils of sandy open cerrado vegetation. Its known populations are currently under protection of JPA. According to collectors and published literature (Schimidt et al. 2007), dry season fires are very common in the Jalapão region and is hard to find areas unburned for more than 3 years. Thus, Dioscorea compacta may be resistant to fires, surviving due to its underground system.

CONSERVATION STATUS. There are few known populations of Dioscorea compacta, three registered inside a perimeter of $15 \mathrm{~km}$ and another $60 \mathrm{~km}$ away. They cover an EOO of $314 \mathrm{~km}^{2}$, with an AOO of $16 \mathrm{~km}^{2}$ (cell size of $4 \mathrm{~km}^{2}$ ); both values are below the threshold for Endangered in the IUCN (2012) conservation status assessment, $5000 \mathrm{~km}^{2}$ and $500 \mathrm{~km}^{2}$, criteria $\mathrm{B} 1$ and $\mathrm{B} 2$ respectively. The cerrado of Jalapão is under the increasing threat of burning where the surrounding areas are turned into cattle ranches or grain plantations. Most of the threats come from less than $100 \mathrm{~km}$ to the east, in the northwestern state of Bahia.

PHENOLOGY. Flowering and fruiting during the wet season, between November and February.

ETYMOLOGY. We named this species "compacta" for its compact growth and inflorescences, especially the pistillate ones.

NOTES. At first sight, Dioscorea compacta resembles the dwarf occasional climbers $D$. anomala, D. maianthemoides and D. stenophylla, herein called D. anomala complex, but is clearly distinct by the number of stamens, number of staminodia in the pistillate flower and the seed shape, characters summarised in Table 1. Another dwarf, D. perdicum is similar because of its short inflorescences and 3-staminate flowers, but distinct because of the absence of either pistillodia or staminodia in staminate and pistillate flowers, respectively. Besides D. compacta, the 


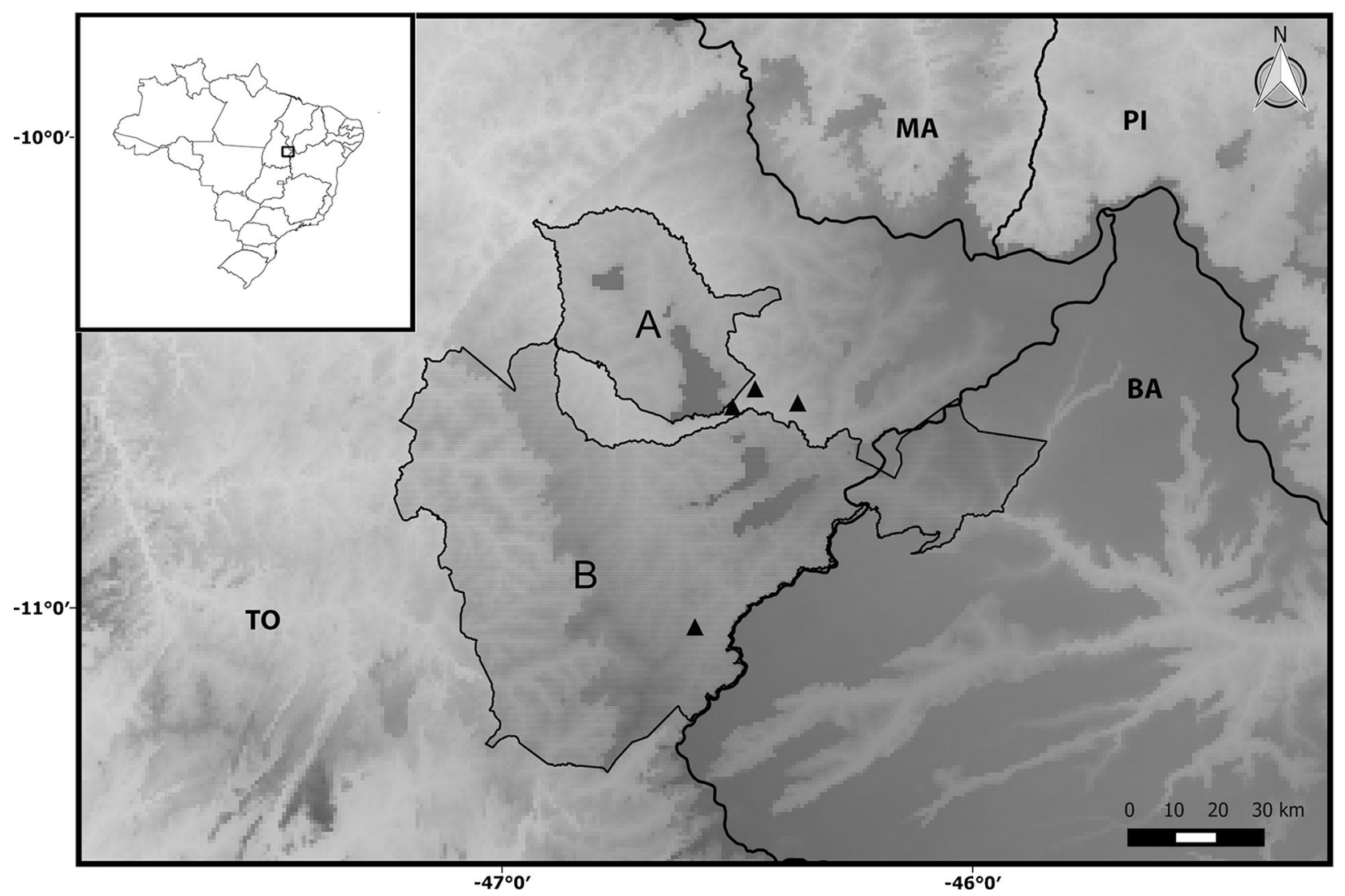

Map 1. Geographic distribution of Dioscorea compacta ( $\mathbf{\Delta}$ ). A Protected Area of Parque Estadual do Jalapão. B Protected Area of Estação Ecológica da Serra Geral do Tocantins. States: BA Bahia; MA Maranhão; PI Piauí; TO Tocantins.

only Brazilian species that combine dwarf growing and spherical unwinged seeds in 3-winged capsules - as appear in some Epipetrum — is the recently discovered D. sphaeroidea. In Mexico, D. minima and D. multinervis are very similar to $D$. compacta due to its short pistillate inflorescences and spheroid rugose seeds, but distinct by the absence of staminodia in the staminate flower. The tubers of neotropical dwarf species are perennial and the aerial stem is dextrorse, so this may place them in the second of two New World clades as shown by Wilkin et al. (2005). A more focused phylogenetic approach is necessary to understand the rise of dwarf Dioscorea in the Neotropics.

According to Burkill (1960), dwarf species from open vegetation tend to have lost the seed wings. In contrast, the Dioscorea anomala complex and $D$. perdicum have circular wings in their flattened seeds. However, the same author stated that seeds with such

Table 1. Comparison of morphological characters of Brazilian dwarf Dioscorea species similar to D. compacta.

\begin{tabular}{|c|c|c|c|c|c|c|c|}
\hline & & D. compacta & D. sphaeroidea & D. maianthemoides & D. stenophylla & D. perdicum & D. anomala \\
\hline Habit & & $\begin{array}{l}\text { sometimes } \\
\text { climbing }\end{array}$ & $\begin{array}{l}\text { sometimes } \\
\text { climbing }\end{array}$ & $\begin{array}{l}\text { sometimes } \\
\text { climbing }\end{array}$ & $\begin{array}{l}\text { sometimes } \\
\text { climbing }\end{array}$ & non-climbing & non-climbing \\
\hline Leaf & $\begin{array}{l}\text { Shape } \\
\text { Texture }\end{array}$ & $\begin{array}{l}\text { wider than long } \\
\text { membranaceous }\end{array}$ & $\begin{array}{l}\text { wider than long } \\
\text { membranaceous }\end{array}$ & $\begin{array}{l}\text { longer than wide } \\
\text { coriaceous }\end{array}$ & $\begin{array}{l}\text { longer than wide } \\
\text { coriaceous }\end{array}$ & $\begin{array}{l}\text { longer than wide } \\
\text { coriaceous }\end{array}$ & $\begin{array}{l}\text { longer than wide } \\
\text { coriaceous }\end{array}$ \\
\hline $\begin{array}{c}\text { Estaminate } \\
\text { Flowers }\end{array}$ & $\begin{array}{l}\text { No of } \\
\text { stamens }\end{array}$ & 6 & 3 & 6 & 6 & 3 & 6 \\
\hline \multirow[t]{2}{*}{$\begin{array}{l}\text { Pistillate } \\
\text { Flowers }\end{array}$} & Style Length & $1 \mathrm{~mm}$ & $0.5 \mathrm{~mm}$ & $1 \mathrm{~mm}$ & $1 \mathrm{~mm}$ & $0.5 \mathrm{~mm}$ & $1 \mathrm{~mm}$ \\
\hline & Staminodes & 3 & 3 & 6 & 6 & 3 & 6 \\
\hline Seeds & $\begin{array}{l}\text { Shape } \\
\text { Wings }\end{array}$ & $\begin{array}{l}\text { rounded } \\
\text { absent }\end{array}$ & $\begin{array}{l}\text { rounded } \\
\text { absent }\end{array}$ & $\begin{array}{l}\text { flattened } \\
\text { present }\end{array}$ & $\begin{array}{l}\text { flattened } \\
\text { present }\end{array}$ & $\begin{array}{l}\text { flattened } \\
\text { present }\end{array}$ & $\begin{array}{l}\text { flattened } \\
\text { present }\end{array}$ \\
\hline
\end{tabular}


wings can glide in very light air but are less effective in strong wind, which is the prevailing condition in those environments. Non South American wingless seeded species are zoochoric (Wilkin pers. comm.) and the carunculate seeds of Epipetrum (Viruel et al. 2010) in South America are suggested to be the same. On the other hand, once D. compacta is fruiting in the last month of the rainy season, the rounded colliculate light seeds probably still depends on the wind for dispersal, instead of flying, rolling or even being carried by small streams among the bushes. We noticed predation of the staminodes in many staminate flowers, which can be confusing for proper determination but calls attention to an interesting feature for the study of the plantpredator/pollinator relationship.

\section{Acknowledgements}

We thank Laura Montserrat for providing the line drawing; Jalapão State Park and Serra Geral do Tocantins Ecological Station crew for field support; Ubiratan Chagas, Lucas Nascimento, Marcela Escaramai, Heloisa Antar, Vera Scatena, Paulo Sano, Rebeca Viana and Marcio Martins for help during field work. Thanks to Dr Paul Wilkin for the attentive personal communication. GMA thanks "Coordenação de Aperfeiçoamento de Pessoal de Nível Superior", "Fundação de Amparo à Pesquisa do Estado de São Paulo" (2014/01851-7) and Idea Wild, DA thanks to "Conselho Nacional de Desenvolvimento Científico e Tecnológico" (158553/2011-0), for financial support. Special thanks to two anonymous reviewers for their advice.

\section{References}

Bachman, S., Moat, J., Hill, A. W., de la Torre, J. \& Scott, B. (2011). Supporting Red List threat assessments with GeoCAT: geospatial conservation assessment tool. ZooKeys 150: 117 - 126.

Burkill, I. H. (1960). The organography and the evolution of Dioscoreaceae, the family of the Yams. Bot. J. Linn. Soc. 56: 319 - 412.

Caddick, L. R., Wilkin, P., Rudall, P. J., Hedderson, T. A. J. \& Chase, M. W. (2002). Yams reclassified: a recircunscription of Dioscoreaceae and Dioscoreales. Taxon 51: 103 - 114.

Couto, R. S., Lopes, C. R. \& Braga, J. M. A. (2014). Dioscorea sphaeroidea (Dioscoreaceae), a threatened new species from the high-altitude grasslands of southeastern Brazil with wingless seeds. Phytotaxa 163(4): $229-234$.

E-monocot (2015). EMonocot, An online resource for monocot plants http://e-monocot.org/ (accessed 18 August 2015).
Forzza, R. C., Baumgratz, J. F. A., et al. (2012). New Brazilian floristic list highlights conservation challenges. BioScience 62: 39 - 45.

IUCN (2012). IUCN Red List Categories and Criteria. Version 3.1 2nd ed. IUCN, Gland and Cambridge.

Kirizawa, M., Xifreda, C. C., Couto, R. \& Araújo, D. (2015). Dioscoreaceae. Lista de Espécies da Flora do Brasil. Jardim Botânico do Rio de Janeiro.http:// floradobrasil.jbrj.gov.br/jabot/floradobrasil/ FB7372. Accessed 20 April 2015.

Klink, C. A. \& Machado, R. B. (2005). Conservation of Brazilian Cerrado. Conservation Biol. 19(3): 707 - 713.

Knuth, R. (1924). Dioscoreaceae. In: H. G. A. Engler (ed.), Das Pflanzenreich 4, 43 (87): 1 - 387. Verlag von Wilhelm Engelmann, Leipzig.

Pedralli, G. (2002). Levantamento florístico das Dioscoreaceae (R. Br.) Lindley da Cadeia do Espinhaço, Minas Gerais e Bahia, Brasil. Bol. Bot. Univ. São Paulo 20: 63 - 119.

Proença, C. E. B., Farias-Singer, R. \& Gomes, B. M. (2007). Pleonotoma orientalis (BignoniaceaeBignonieae): Expanded description, distribution and a new variety of a poorly known species. Edinburgh J. Bot. 64(1): 17 - 23.

Quantum GIS Development Team (2015). Quantum GIS Geographic Information System. Open Source Geospatial Foundation Project. http:// qgis.osgeo.org.

Ratter, J. A., Ribeiro, J. F. \& Bridgewater, S. (1997). The Brazilian cerrado vegetation and threats to its biodiversity. Ann. Biol. 80: 223 - 230.

Sampaio, M. B., Schmidt, I. B. \& Figueiredo, I. B. (2008). Harvesting Effects and Population Ecology of the Buriti Palm (Mauritia flexuosa L.f., Arecaceae) in the Jalapão Region, Central Brazil. Econ. Bot. 62(2): 171 - 181.

Schimidt, I. B., Figueireo, I. B. \& Scariot, A. (2007). Ethnobotany and Effects of Harvesting on the Population of Syngonanthus nitens (Bong.) Ruhland (Eriocaulaceae), a NTFP from Jalapão Region, Central Brazil. Econ. Bot. 61(1): 73 - 85.

SEPLAN - Secretaria do Planejamento e Meio Ambiente do Estado de Tocantins. (2012). Atlas do Tocantins: Subsidios ao Planejamento da Gestão Territorial. Seplan, Palmas.

Silva, J. M. C. \& Bates, J. M. (2002). Biogeographic patterns and conservation in the South America Cerrado: A Tropical Savana Hotspot. BioScience 52(3): $225-233$.

Sosa, V. \& Valdivieso, I. G. (2013). Dioscoreaceae. In: G. C. Rzedowski \& J. Rzedowski (eds), Flora del Bajio y de Regiones Adyacentes 177. Instituto de Ecología, A.C., México. 
Thiers, B. [continuously updated]. Index Herbariorum: A global directory of public herbaria and associated staff. New York Botanical Garden's Virtual Herbarium. http://sweetgum.nybg.org/ih. Accessed 02 September 2015.

Viruel, J., Segarra-Moragues, J. G., Pérez-Collazos, E., Villar, L. \& Catalán, P. (2010). Systematic Revision of the Epipetrum Group of Dioscorea (Dioscoreaceae) Endemic to Chile. Syst. Bot. 35(1): $40-63$.
Wilkin, P., Schols, P., Chase, M. W., Chayamarit, K., Furness, C. A., Huysmans, S., Rakotonasolo, F., Smets, E. \& Thapyai, C. (2005). A plastid gene phylogeny of the yam genus, Dioscorea: Roots, fruits and Madagascar. Syst. Bot. 30: 736 - 749.

, Muasya, A. M., Banks, H., Furness, C. A., Vollesen, K., Weber, O. \& Sebsebe, D. (2009). A New Species of Yam from Kenya, Dioscorea kituiensis: Pollen Morphology, Conservation Status, and Speciation. Syst. Bot. 34(4): 652 - 659 . 